\title{
Trends of water quantity and water quality of the Yellow River from 1956 to 2009: implications for the effect of climate change
}

\author{
Qiong Wu and Xinghui Xia*
}

\begin{abstract}
Background: Based on the monthly data of river runoff and major ion contents of the mainstream of the Yellow River during the period of 1956-2009, the effects of climate change on the trends of water quantity and major ion contents have been analyzed.

Results: The main conclusions have been drawn as follows: 1) The river runoff showed a significant decreasing trend from 1956 to 2009. 2) Total ion contents showed an increasing trend during this period, and there was a significantly negative correlation between the river runoff and total ion contents of the river. 3) There were two probable reasons for the increasing trends of major ion concentrations in the Yellow River. One was that the increasing of temperature caused by climate change enhances rock weathering; the other was that the decreasing trends of river runoff weaken its dilution effect for major ions in river water.

Conclusions: The results obtained in this research implicates that climate change will affect the major ion chemistry and water quality of the Yellow River. Further researches are needed to study the effects of climate change on water quality and water environment.
\end{abstract}

Keywords: Climate change; River runoff; Water quantity; Water quality; Major ions; The Yellow River

\section{Background}

Due to the consumption of fossil fuels and other anthropogenic activities, the emission of greenhouse gases has increased, which have induced global climate change with warming as the significant feature (Jones et al. 2009). Intergovernmental Panel Climate Change (IPCC) report points out that the earth's surface temperature increased by $0.74^{\circ} \mathrm{C}$ during the last 100 years (1906-2005). Therefore, the global warming has been an indisputable fact at present Alley et al. 2007). It may lead not only to a substantial temperature rising but also to a new pattern of surface water resources (Porcal et al. 2009). The IPCC reports indicate that precipitation of some areas shows significant increasing trends, such as South America and east area in North America, while it exhibits the trend of droughts in the Mediterranean. From the above, we can easily draw the conclusion that climate change can

\footnotetext{
* Correspondence: xiaxh@bnu.edu.cn

State Key Laboratory of Water Environment Simulation/School of Environment, Beijing Normal University, Beijing 100875, China
}

influence the spatial distribution of water resources. Although the processes are uncertain, climate change is expected to produce drier summers and wetter winters across many places in the world (Arnell 2004; Chaplot 2007). In China, some researches have exhibited that climate change can impact the monthly variation of water quantity of rivers such as the Yellow River and the Heihe River (Hao et al. 2006; Zhang et al. 2007a; Qin et al. 2010).

Not only water quantity but also water quality can be affected by climate change. There are also some evidences indicate that climate change can influence water quality worldwide (Wolfram \& Heike 2009; Burton et al. 2010; Huang et al. 2010). According to some research, the changes of precipitation, temperature, radiation, and wind caused by climate change will affect migration and transformation pathways as well as other biochemistry processes of pollutants in environment. It will lead to the change of reaction rate constant, adsorption rate, and dynamic constants of bioaccumulation of pollutants, resulting in the change of water quality (Frisk et al. 1997; Yu et al. 2002; Schiedek et al. 2007; Elias \& Elias 
2010). Therefore, climate change is an important factor affecting both water quantity and quality in rivers. Mimikou et al. (2000) have studied the effects of regional climate change on water quality in the Pinios river basin situated in the central part of Greece, and Prathumraana et al. (2008) have studied the lower Mekong River in Indochina; their results showed that the decrease of mean monthly runoff induced by climate change had led to the degradation of water quality. In addition, Jenet et al. (2010) have studied the impacts of regional climate change on water quality in the MurrayDarling Basin, Australia, and their results showed that regional climate changes, particularly increase in temperature and decrease in runoff volume, can also influence water quality. However, there are few research reports about the effect of climate change on water quality and quantity as well as the relationship between them of a river for a long period.

Therefore, this research took the Yellow River as an example to study the effect of climate change on water quantity and quality, especially the relationships between them. In detail, based on the monthly data of river runoff and major ion concentrations of the mainstream of the Yellow River during the period of 1956-2009, the effects of climate change on the trends of water quantity and major ion concentrations have been analyzed.

\section{Methods}

Introduction of the study area

The Yellow River is the second largest river in China which originates from the Tibetan Plateau, flows eastwards through the Loess Plateau and the North China Plain, inrushes into the Bohai Sea at Kenli County, Shandong Province, with the mainstream length of 5464 $\mathrm{km}$ and basin area of $752000 \mathrm{~km}^{2}$. The river is divided into the upper, middle and lower reaches based on its geomorphology and climatic conditions. According to the Yellow River Water Resources Bulletin of 2008, the upper reaches are the section from the river source to Toudaoguai, where the climate is arid with an annual average precipitation of $396 \mathrm{~mm}$. The middle reaches stretch from Toudaoguai to Huayuankou; this section is mainly located in the Loess Plateau with lots of tributaries. The climate is semiarid and arid with an annual average precipitation of $516 \mathrm{~mm}$. The lower reaches stream down from Huayuankou; the climate is humid with an annual average precipitation of $648 \mathrm{~mm}$.

The study on impacts of climate changes on the Yellow River basin is of great significance to the river management under climate change because of its growing economic and agricultural importance in China. Changes of water quality and quantity are of significance to water supply and demand in the Yellow River basin (Xia et al. 2009a). Though there have been numerous

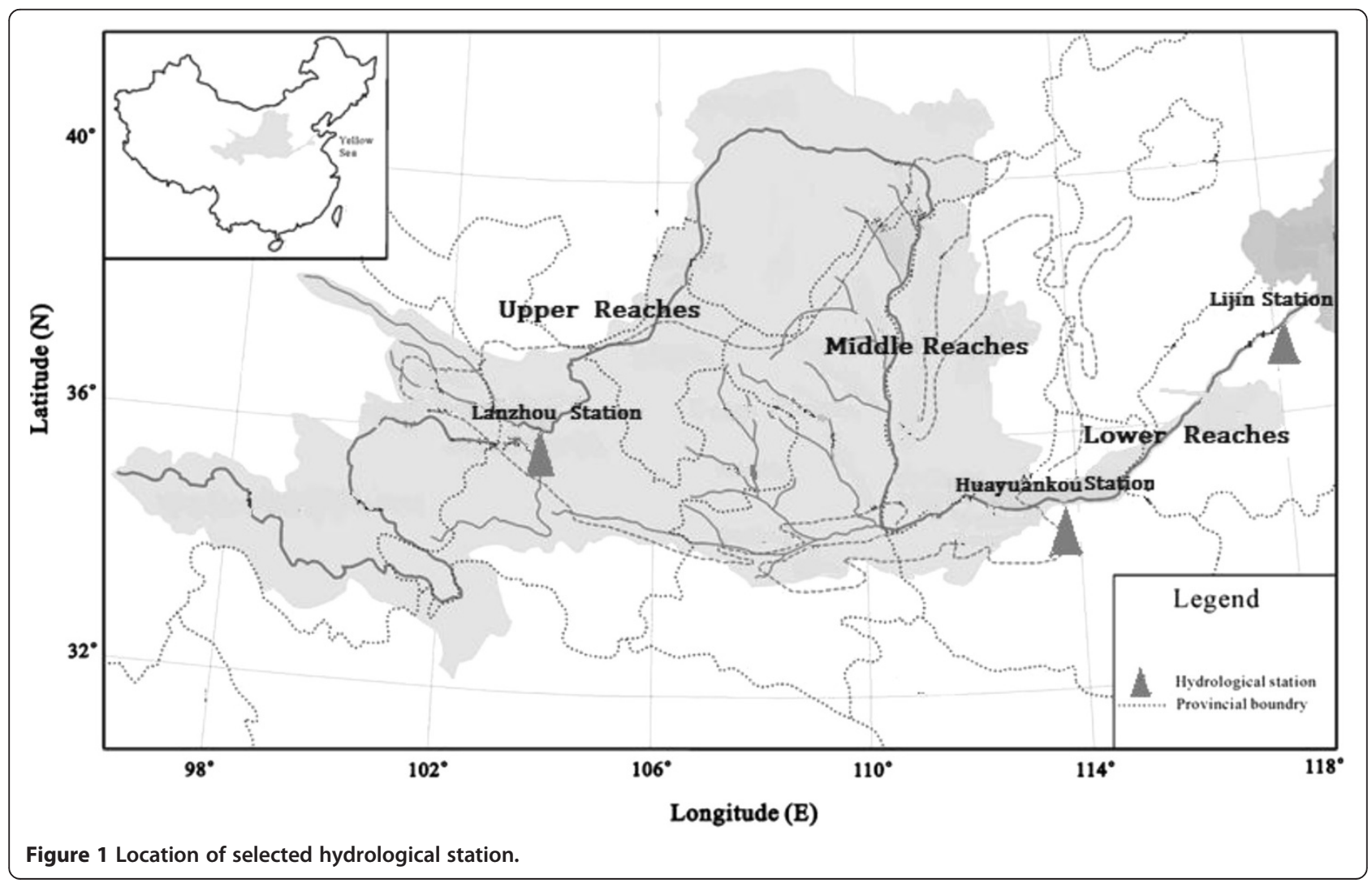



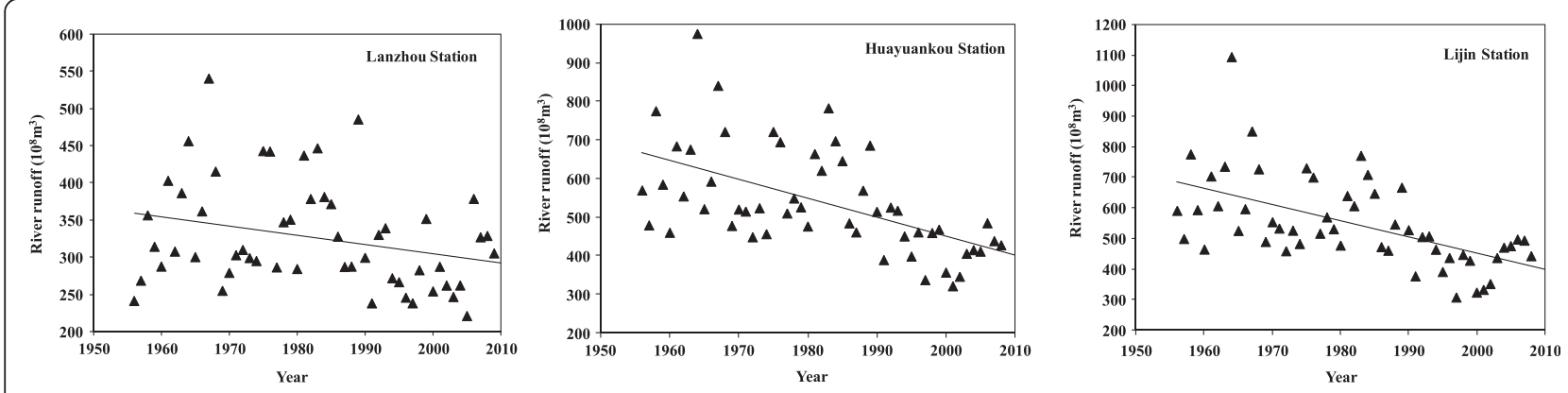

Figure 2 The variation trend of annual natural runoff from 1956 to 2009.

studies about the water quantity and quality in the Yellow River (Xia et al. 2009b; Yuan \& Shu 2008), few studies have been conducted on the effect of climate changes on the water quantity and quality of this river.

\section{Data sources and methods}

Three hydrological stations were studied in this research, which were the Lanzhou Station in the upper reaches, the Huayuankou Station in the middle reaches, and the Lijin Station in the lower reaches (Figure 1). Monthly water quality and quantity data of the three stations from 1956 to 2009 were retrieved from the Yellow River Conservancy Commission. Water quality parameters included $\mathrm{Ca}^{2+}, \mathrm{Mg}^{2+}, \mathrm{K}^{+}$, $\mathrm{Na}^{+}$, total ion concentrations, conductivity, $\mathrm{pH}$ and dissolved oxygen (DO). Water quantity data included river runoff. Based on the monthly data of river runoff and water quality parameters of the three stations from 1956 to 2009, the variation trends of the river runoff, major ion concentrations and other water quality parameters in the Yellow River were determined by chi-square test with SPSS 18.0 software (SPSS Inc., USA), and relationship between water quantity and water quality parameters of the Yellow River was studied by Pearson coefficient method.

\section{Results and discussion}

The variation of water quantity

As shown in Figure 2, the annual natural runoff of the Yellow River showed a significant decreasing trend from 1956 to 2009 at the Lanzhou Station, Huayuankou Station and Lijin Station, and the decreasing extents were about $8010^{8} \mathrm{~m}^{3}, 28010^{8} \mathrm{~m}^{3}$ and $30010^{8} \mathrm{~m}^{3}$ during the last 50 years, respectively. In addition, there was difference in river runoff trends among different seasons and different stations. For the Lanzhou Station, as shown in Figure 3, the river runoff exhibited an increasing trend in June, but decreased in wet seasons. At the same time, for the Huayuankou Station in the middle reaches and the Lijin Station in the lower reaches, the river runoff showed decreasing trends in each month, and the decreasing rates in wet season were higher than the other seasons.

These results can be explained by changes of precipitation and temperature caused by climate change in the Yellow River basin. There have been findings about decrease of precipitation in the Yellow River basin during the past 50 years (Lan et al. 2006; Zhang et al. 2009). In addition, the annual mean temperature has increased $0.6^{\circ} \mathrm{C}$ in the Yellow River from 1950 to 2000 (Qiu et al. 2003), especially after 2000 , the mean annual temperature is $1^{\circ} \mathrm{C}$ higher than the 1950s (Yang et al. 2009), and regional climate models predict that the temperature will increase
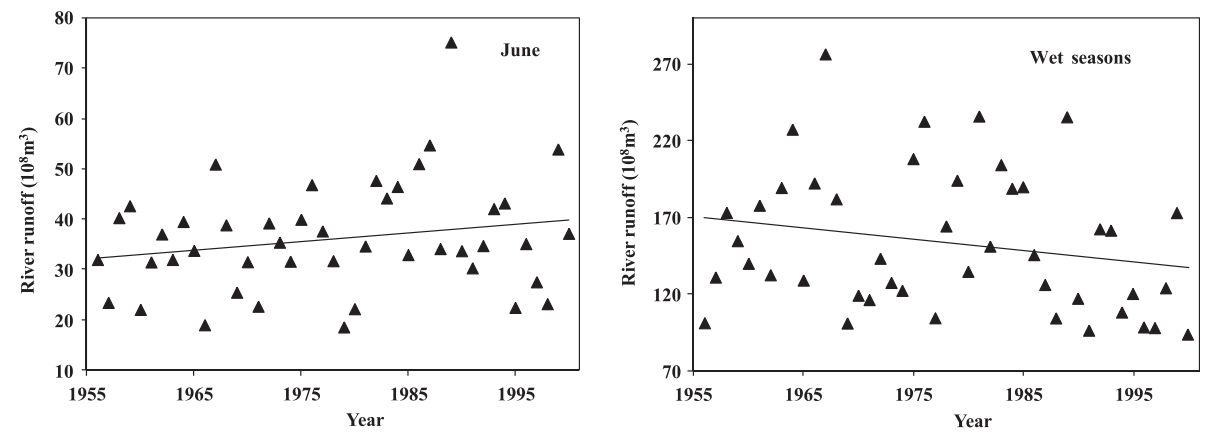

Figure 3 The variation trend of river runoff at the Lanzhou Station in June and wet seasons (including July, August, September) from 1956 to 2000. 

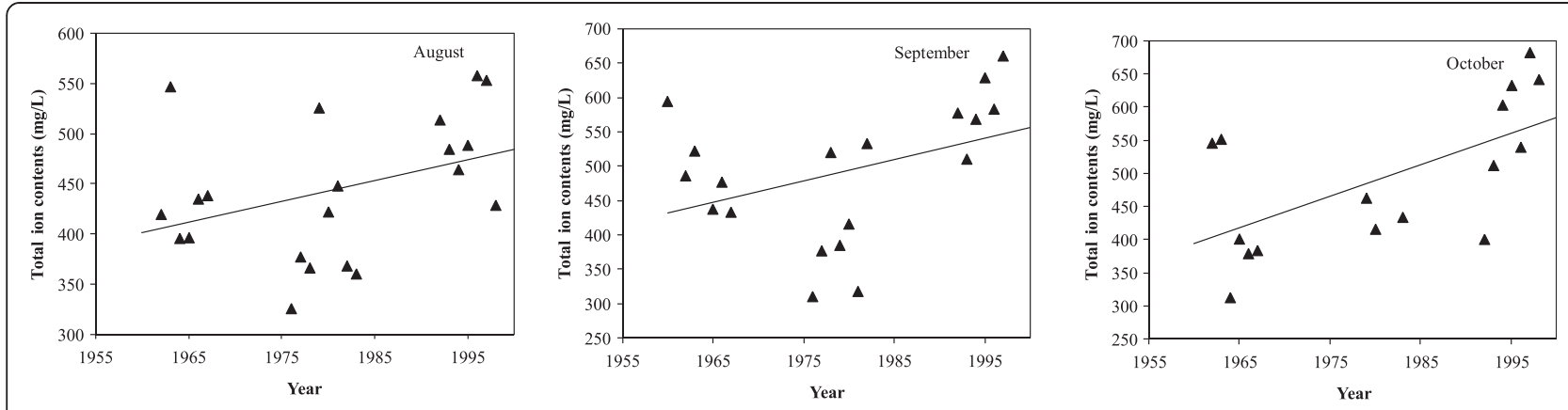

Figure 4 The variation trend of total ion contents at the Huayuankou Station.

by $3.44 \sim 3.90^{\circ} \mathrm{C}$ at the end of the 21st century (Yao et al. 2009). The increase of temperature in the basin will lead to the increase of evaporation. Therefore, the decrease of precipitation and increase of evaporation have resulted in the decrease of river runoff of the Yellow River.

\section{The variation of total ion contents and other water quality parameters}

The concentrations of total ions, $\mathrm{Ca}^{2+}$, and $\mathrm{Mg}^{2+}$ in the Yellow River showed increasing trends from 1960 to 2000, especially obvious in wet seasons at the Lanzhou and Huayuankou stations (Figure 4). For the Huayuankou station, in addition to wet seasons, monthly averages of total ion concentrations, and $\mathrm{Ca}^{2+}, \mathrm{Mg}^{2+}$ concentrations in the other seasons increased from 1960 to 2000. And, electrical conductivity had strong relationship with total ion concentration at the Huayuakou Station; it also increased in wet seasons. Electrical conductivity represents the amount of total dissolved solids or total amount of dissolved ions in water. The increasing conductivity means higher dissolved ion concentrations in water (Kenneth et al. 2005).

$\mathrm{pH}$ was also analyzed as one of water quality parameters. From Figure 5, it's obvious to find the decreasing trend of $\mathrm{pH}$ from 1992 to 2000. This was probably caused by the increasing emissions of acid rain precursors such as $\mathrm{SO}_{2}$ and $\mathrm{NO}_{\mathrm{x}}$ (Ji-Hyung et al. 2010), which could be brought into the rivers through wet deposition. In addition, decreased water level could accelerate the oxidation process of sulfide of the riverbed. (Aherne et al. 2006) and (Laudon 2007) also obtained the similar results. (Aherne et al. 2006) reported that recent recovery of surface waters from acidification has been delayed by drought induced $\mathrm{SO}_{4}^{2-}$ export from wetlands in south-central Ontario, Canada. According to Laundon's research (Laudon 2007), recovery from episodic acidification was delayed by drought and high sea salt deposition in Sweden. In addition to that, (Evans et al. 2007) found that frequent storms in the winter caused by climate change brought more acid ions such as $\mathrm{SO}_{4}^{2-}$ to rivers, leading to the decrease of $\mathrm{pH}$ in a small, moorland stream in mid-Wales, UK.

Another water quality parameter DO was also analyzed, but the variation trend was not obvious. This was probably because that DO content was not only influenced by temperature, river runoff, but also by conditions of water exchange and biological activities (Zhang et al. 2007b); the organic matters transported from land to river by precipitation were assimilated by aerobic organisms using DO. Therefore, DO could not reflect the relationship between water quantity and water quality well. Prathumraana et al. (2008) also reported that DO had weak correlations with river runoff.

Relationship between water quantity and quality was analyzed based on the historical data of river runoff and total ion concentrations, $\mathrm{Ca}^{2+}$ and $\mathrm{Mg}^{2+}$ concentrations. Results in Table 1 and Figure 6 revealed the significant correlations between river runoff and water quality

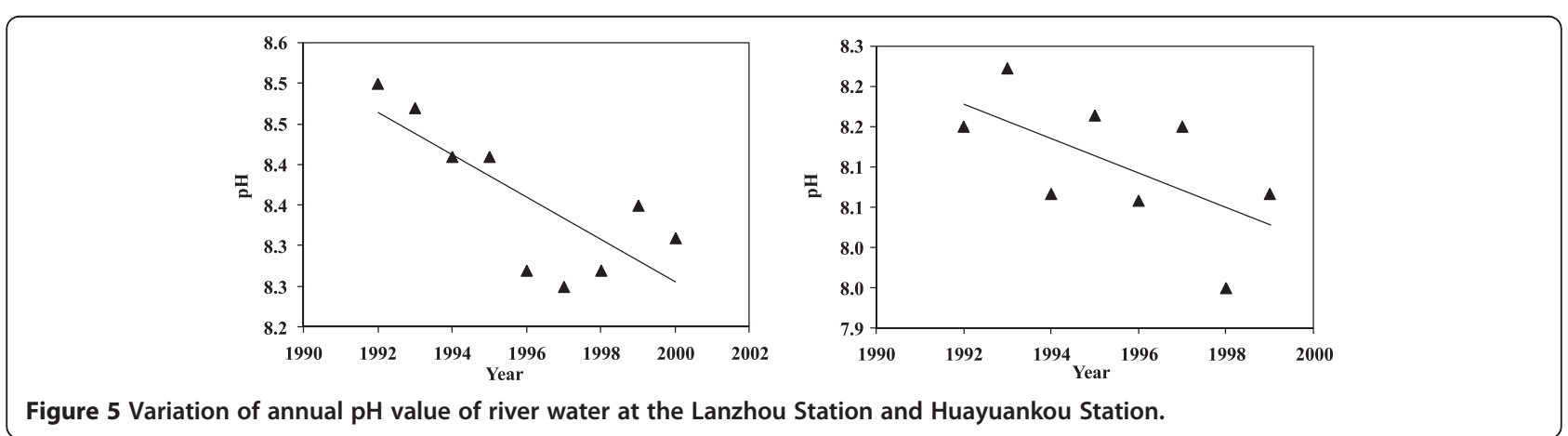


Table 1 Correlations of river runoff and major ion concentrations of the Yellow River at the Lanzhou and Huayuankou Station

\begin{tabular}{|c|c|c|c|c|c|c|}
\hline \multirow[t]{2}{*}{ Parameters } & \multicolumn{3}{|c|}{ Runoff of Lanzhou station } & \multicolumn{3}{|c|}{ Runoff of Huayuankou station } \\
\hline & August & September & October & August & September & October \\
\hline $\mathrm{Ca}^{2+}$ (Aug.) & $-0.338^{*}$ & & & -0.302 & & \\
\hline $\mathrm{Ca}^{2+}(\mathrm{Sep})$. & & -0.133 & & & -0.237 & \\
\hline $\mathrm{Ca}^{2+}(\mathrm{Oct})$. & & & -0.007 & & & $-0.668^{* *}$ \\
\hline $\mathrm{Mg}^{2+}$ (Aug.) & -0.250 & & & -0.324 & & \\
\hline $\mathrm{Mg}^{2+}$ (Sep.) & & $-5.44^{* *}$ & & & $-0.447^{*}$ & \\
\hline $\mathrm{Mg}^{2+}$ (Oct.) & & & -1.25 & & & $-0.597^{* *}$ \\
\hline Total ions (Aug.) & $-0.419^{*}$ & & & -0.364 & & \\
\hline Total ions (Sep.) & & $-4.12^{*}$ & & & $-0.461^{*}$ & \\
\hline Total ions (Oct.) & & & -0.074 & & & $-0.672^{* *}$ \\
\hline
\end{tabular}

*Correlation is significant at the 0.05 level.

${ }^{* *}$ Correlation is significant at the 0.01 level.

parameters of the Yellow River. Ion concentrations showed significantly negative correlation with river runoff, especially for the Huayuankou Station in August, September and October and for the Lanzhou Station in July. The results are similar to those obtained by (Wright \& Worral 2001), who reported that conductivity and a selection of metal ion concentrations such as $\mathrm{Ca}^{2+}$ and $\mathrm{Mg}^{2+}$ showed an inverse relationship with river flow in Tees estuary of the United Kingdom. It is suggested that $\mathrm{Ca}^{2+}$ and $\mathrm{Mg}^{2+}$ are mostly sourced from dissolution of rocks of the catchment; they enter river through base flow input. Higher river flow will dilute the concentration of these ions; on the contrary, lower runoff will increase the concentration of these ions (Chen et al. 2002). The results obtained in this research indicated that major ion concentrations have response to the change of river runoff.

Implications for the effect of climate change on the water quality and quantity of the Yellow River

There were two probable reasons for the increasing trends of major ion concentrations in the Yellow River. One was that the increasing of temperature caused by climate change enhances rock weathering, leading to the higher concentrations of major ions in river water. The other reason was that the decreasing trends of river runoff weaken its dilution effect for major ions in river water, resulting in the concentration of major ions. This was manifested by the negative correlation between river runoff and total ion concentrations. The decreasing trend of river runoff of the Yellow River and the increase of temperature were mainly caused by the climate change (Zeng et al. 2004; Liu 2007; Jia et al. 2008). Therefore, the results obtained in this research implicates that climate change will affect the water quality including major ion concentrations, conductivity and $\mathrm{pH}$ value of rivers.

\section{Conclusion}

This research has shown the significant decreasing trend of water quantity and the increasing trend of major ion concentrations as well as the effects of climate change on both water quantity and quality of the Yellow River. Climate change has already produced a variety of unpredictable effects on water resources including water quantity and quality. Appropriate measures should be
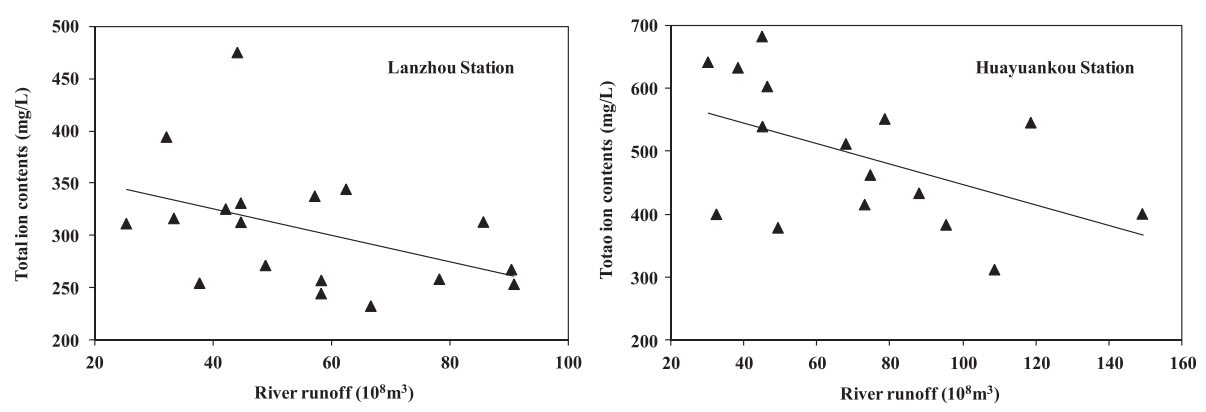

Figure 6 Correlations between water quantity and total ion contents at the Lanzhou Station $(p<0.05)$ in July and at the Huayuankou Station $(p<0.05)$ in October. 
put forward to deal with climate change impacts, which can be used to mitigate the bad effects. Specific and practical options and positive ways to enhance adaptability to climate change should be proposed to decisionmakers. To this end, the impact of climate change on water resources and water security should be studied, and further research are needed to study the effects of climate change on water quality and eco-environment of surface water.

\section{Competing interests}

The authors declare that they have no competing interests.

\section{Authors' contributions}

WQ carried out the data analysis and drafted the manuscript. XXH provided the conceptual guidance and polished the manuscript. Both authors read and approved the final manuscript.

\section{Acknowledgements}

This study was supported by the Major State Basic Research Development Program (2010CB951104) and National Science Foundation for Distinguished Young Scholars (51325902).

Received: 29 November 2013 Accepted: 7 January 2014

Published: 10 January 2014

\section{References}

Aherne J, Larssen T, Cosby BJ, Dillon PJ (2006) Climate variability and forecasting surface water recovery from acidification: modelling drought-induced sulphate release from wetlands. Sci Total Environ 365:186-99

Alley R, Berntsen T, Bindoff NL, et al. (2007) Climate Change 2007: The physical science basis, summary for policymakers, Intergovernmental Panel on Climate Change (IPCC). Geneva, Switzerland

Arnell NW (2004) Climate change impacts on river flows in Britain: the UKCIP02scenarios. Water Environ J 18:112-117

Burton A, Fowler HJ, Blenkinsop S, Kilsby CG (2010) Downscaling transient climate change using a Neyman-Scott Rectangualr Pulses stochastic rainfall model. J Hydrol 381:18-32

Chaplot V (2007) Water and soil resources response to rising levels of atmospheric $\mathrm{CO}_{2}$ concentration and to changes in precipitation and air temperature. J Hydrol 337(1-2):159-171

Chen JS, Wang FY, Xia XH, Zhang LT (2002) Major element chemistry of the Changjiang (Yangtze River). Chem Geol 187:231-255

Elias D, Elias M (2010) Hydrological and nitrogen distributed catchment modeling to assess the impact of future climate change at Trichonis Lake, western Greece. Hydrogeol I 18:441-454

Evans CD, Reynolds B, Hinton C, Hughes S, Norris D, Grant S (2007) Effects of decreasing acid deposition and climate change on acid extremes in an upland stream. Hydrol Earth Syst Sci Discuss 4:2901-2944

Frisk T, Bilaetdin A, Kallio K, Saura M (1997) Modelling the effects of climatic change on lake eutrophication. Boreal Environ Res 2:53-57

Hao ZC, Wang JC, Wang ZH, Wang L (2006) Impact of climate change on runoff in source region of Yellow River. J Glaciol Geocryol 28(1):1-7 (in Chinese)

Huang SC, Valentina K, Hermann O, Fred FH (2010) Simulation of spatiotemporal dynamics of water fluxes in Germany under climate change. Hydrol Processs 24:3289-3306

Jenet A, Zhang L, Roger NJ, Paul D, Warrick D, Peter H (2010) Climate change impact on water and salt balances: an assessment of the impact of climate change on catchment salt and water balances in the Murray-Darling Basin, Australia. Clim Change 100:607-631

Jia YW, Gao H, Niu CW, Qiu YQ (2008) Impact of climate change on runoff process in headwater area of the Yellow River in Chinese. Shuili Xuebao 39 (1):52-58 (in Chinese)

Ji-Hyung P, Lei D, Bomchul K, Myron JM, Hideaki S (2010) Potential effects of climate change and variability on watershed biogeochemical processes and water quality in Northeast Asia. Environ Int 36:212-225

Jones PG, Thornton PK, Heinke J (2009) Generating characteristic daily weather data using downscaled climate model data from the IPCC's Fourth Assessment. ILRI
Kenneth WT, Lancaster DL, Morrison JA, Lile DF, Sado Y, Huang B (2005) Monitoring helps reduce water-quality impacts in flood-irrigated pasture. Calif Agric 59(3):167-175

Lan YC, Shen YP, Li ZY, Liu JQ, Ma JH (2006) Influence of global warming on water resources system in the riverhead area of the Yellow River. J of Arid Land Resour and Environ 20(6):57-62 (in Chinese)

Laudon H (2007) Recovery from episodic acidification delayed by drought and high sea salt deposition. Hydrol Earth Syst Sci Discuss 4:2975-2996

Liu CZ (2007) The advances in studying detection of streamflow trend influenced by climate change. Adv in Earth Sci 22(8):777-782 (in Chinese)

Mimikou MA, Baltas E, Varanou E, Pantazis K (2000) Regional impacts of climate change on water resources quantity and quality indicators. J Hydrol 234:95-109

Porcal P, Koprivnjak JF, Dillon PJ, Molot LA (2009) Humic substances-part 7: the biogeochemistry of dissolved organic carbon and its interactions with climate change. Environ Sci Pollut Res 16:714-726

Prathumraana L, Sthiannopkao S, Woong KK (2008) The relationship of climatic and hydrological parameters to surface water quality in the lower Mekong River. Environ Int 34:860-866

Qin NX, Chen X, Fu GB, Zhai JQ, Xue XY (2010) Precipitation and temperature trends for the Southwest China: 1960-2007. Hydrol Process 24:3733-3744

Qiu XF, Liu CM, Zeng Y (2003) The evaporation pan characteristics of the Yellow River during the past 40 years under climate change. J of Nat Resour 18 (4):437-442 (in Chinese)

Schiedek D, Sundelin B, Readman JW, Macdonald RW (2007) Interactions between climate change and contaminants. Mar Pollut Bull 54:1845-1856

Wolfram M, Heike B (2009) PROMET-Large scale distributed hydrological modeling to study the impact of climate change on the water flows of mountain watershed. J Hydrol 376:362-377

Wright J, Worral F (2001) The effects of river flow on water quality in estuarine impoundments Physics and Chemistry of the Earth, Part B. Hydrol Oceans Atmos 26(9):741-746

Xia XH, Yang ZF, Wu YX (2009a) incorporating eco-environmental water requirements in integrated evaluation of water quality and quantity - a study for the Yellow River. Water Resour Manag 23:1067-1079

Xia XH, Yang ZF, Zhang XQ (2009b) Effect of suspended-sediment concentration on nitrification in river water: importance of suspended sediment-water interface. Environ Sci Technol 43:3681-3687

Yang TQ, Rao SQ, Chen DL (2009) Analysis of temperature and precipitation in the Yellow River basin since 1951. Yellow River 31(10):76-77 (in Chinese)

Yao WY, Xu ZX, Wang YZ (2009) Analysis of runoff variation in Yellow River Basin on the background of climate change. Meteorological and Environ Sci 32 (2):1-5 (in Chinese)

Yu PS, Yang TC, Wu CK (2002) Impact of climate change on water resources in southern Taiwan. J Hydrol 260:161-175

Yuan J, Shu J (2008) Application of neural network model to prediction of water quality of the Yellow River. J of Ecol and Rural Environ 24(2):49-51. 60 (in Chinese)

Zeng T, Hao ZC, Wang JH (2004) Modelling the runoff under changing climate. J Glaciol Geocryol 26(3):324-332 (in Chinese)

Zhang K, Wang RY, Han HT, Wang XP, Si JH (2007a) The water resources of Hei River response to climate change. Resour Sci 1:77-82 (in Chinese)

Zhang YY, Zhang J, Wu Y, Zhu ZY, et al. (2007b) Characteristics of dissolved oxygen and its affecting factors in the Yangtze Estuary. Environ Sci 28 (8):1649-1654. in Chinese

Zhang JY, Wang GP, He RM, Liu CS (2009) Variation trends of runoffs in the Middle Yellow River basin and its response to climate change. Adv in Water Sci 20(2):153-158 (in Chinese)

doi:10.1186/2193-2697-3-1

Cite this article as: Wu and Xia: Trends of water quantity and water quality of the Yellow River from 1956 to 2009: implications for the effect of climate change. Environmental Systems Research 2014 3:1. 